\title{
Geography of Pilgrimage with Special Reference to Islam
}

Ravi S Singh ${ }^{+*}$ and Sarah Ahmad ${ }^{*}$

\section{Abstract}

Pilgrimage is a spiritual journey during which pilgrims have a religious experience and feel connected to the faith's spiritual legacy. The sacred sites are the spiritual home for pilgrims which they have read and heard about but never visited or experienced before. With little attention paid to the Islamic pilgrimage, especially by geographers, this review paper is an attempt to provide an overview of the subject matter and seek to put forward possible future research directions. This paper provides a systematic description of pilgrimage in Islam by reviewing the literature on the subject, analysing the definitions, characteristics, processes, classification and authorisation of pilgrimage in general followed by an overview of Islamic pilgrimage, that is, Ziyarat by defining key terms, discussing the typology and exploring the neglected dimensions in Islamic pilgrimage studies. The study has brought the relics and saints venerated in the Muslim world into focus, which are the essential causes for the origin and continuation of the Ziyarat tradition. It also points out the different occasions and reasons for performing popular pilgrimage in Islam. And lastly, it discusses the future research dimensions of Islamic pilgrimage.

Keywords: Popular Pilgrimage; Islamic Pilgrimage; Ziyarat; Sacred Places; Sacred Sites

\footnotetext{
† Professor, Department of Geography, Institute of Science; \& Adjunct Faculty: Bhojpuri Study Centre, Banaras Hindu University, Varanasi, UP 221 005, India

${ }^{*}$ Corresponding Author, Email: ravis.singh1@bhu.ac.in, ravisingh.geog@gmail.com

¥ Junior Research Fellow (UGC), Department of Geography, Institute of Science, Banaras Hindu University, Varanasi, UP221005, India

(C) 2021 Singh \& Ahmad. This is an Open Access article distributed under the terms of the Creative Commons Attribution License (http://creativecommons.org/licenses/by/2.0), which permits unrestricted use, distribution, and reproduction in any medium, provided the original work is properly cited.
} 


\section{Introduction}

Every major world religion has influenced people since time immemorial to undertake a spiritual journey. A pilgrimage differs from other forms of travel such as vacation or an adventure. It is an amalgamation of both the physical and spiritual journey to a sacred site. Though the essence of pilgrimages has remained the same, certain factors have influenced its characteristics. However, one thing that remains the same in pilgrimages is the spiritual connection. People then and now visit the holy places for the connection or reconnection to their almighty, whether they want something in this world or for the hereafter. The pilgrimage journey's purpose and meanings could be different from individual to individual, for instance, the healing of ailments, the forgiveness of their sins, spiritual awakening, and strengthening of faith. Nevertheless, one thing that's unique to this religious journey, which all the persons of different faiths in their own pilgrimage sites experience are the close connection to God.

The studies related to pilgrimage has a long tradition and has been explored by various disciplines including anthropology, sociology, religious studies, tourism and hospitality studies (e.g., Beattie, 1983; Berriane, 2015; Desai, 2003; Ferg, 2008; Kessler, 2015; Kinell, 2017; Komaki, 2013; Moufahim \& Lichrou, 2018; Mulder, 2014; Ortis, 2017; Puspitasari et al., 2012; Snyder, 2010; and many more to be named) and is still in the ongoing process of generating new knowledge. In geography as well and particularly to be said in cultural geography, we see different studies done by some eminent scholars who have given the insights of the various geographical phenomenon of pilgrimages. Sopher (1968) was one of the first geographers to initiate the research in the pilgrimage domain. Using the scientific approach, he did the spatial analysis of the Gujarati pilgrims' traffic. Bhardwaj (1983) claims Sopher's work to be the best so far for recognising the significance of pilgrim circulation, which is analysed by field data. The other contributors include Bhardwaj (1983), Jackowski (1987), Nolan (1987),
Rinschede (1986), Rowley (1989). Shair and Karan (1979). These geographers have studied the various dimensions of pilgrimage including the location and distribution of sacred places, routes of the pilgrimages, pilgrim traffics, catchment areas, defining and classifying the holy places in various sizes and scales.

The Islamic pilgrimage is distinguished into two categories. The first is Hajj to Mecca, an obligatory pilgrimage for Muslims and one of Islam's five pillars (Rowley, 1989). Therefore, the Hajj has authorisation from the religion itself. The other Islamic pilgrimage is Umrah which is regarded as a lesser pilgrimage and is not obligatory (Dauda et al., 2019). This Islamic pilgrimage can be performed at any time of the year except for a few exceptions (as discussed later).

Moreover, the Islamic pilgrimage, which has a controversial standpoint in Islam is ziyarat or ziyarah. Ziyarat adds to the category of 'popular pilgrimage' in Islam. Ziyarat means 'visitation'. It is done by both Muslims and non-Muslims to shrines, mosques, tombs which are associated with saints, martyrs, prophets, imams, and other holy personages who can be both men and women (Ebadi, 2016).

This study aims to attempt to provide an overview of the pilgrimage in Islam, examine its importance, develop its typology, and put forward possible future research directions. Accordingly, the paper is organised into four parts. The first part briefly addresses the definition of pilgrimage, its characteristics, processes involved, classification, and pilgrimage authorisation. The following part demonstrates the typology of Islamic pilgrimage. The third part discusses the popular pilgrimage in Islam with reference to its origin, causes of growth and continuation, reasons for performing ziyarat and its contradictory views in the Islamic world. Lastly, the future research issues are indicated.

\section{Understanding Pilgrimage}

'Pilgrim', which means foreign, travelling, or migratory, comes from a Latin word 'peregrinus'; 
pilgrimage is a spiritual journey undertaken by a pilgrim (Park, 2004). Many scholars have attempted to explain the notion of pilgrimage. For instances, Barber (1993, p. 1) defines pilgrimage as "a journey resulting from religious causes, externally to a holy site, and internally for spiritual purposes and internal understanding." While Morinis (1992, p. 4) states "pilgrimage is a journey undertaken by a person in quest of a place or a state that he or she believes to embody a valued ideal;" CollinsKreiner (2010, p. 440) asserts that "pilgrimage is one type of "circulation," which is a form of population mobility." Sykes (1982, p. 776) defines pilgrimage as "a journey to a sacred place as an act of religious devotion". Thus, looking into all these definitions of pilgrimage few elements are common, and it includes: pilgrimage involves a journey backed by religious motives. It entails a starting point which is a known place to the pilgrim and the destination, which is the holy place.

The context of pilgrimage has undoubtedly changed and become more secular. For instance, there is a visitation to the war graves, celebrities' residence, visits to churchyards, and funerary sites. However, the definition of pilgrimage may have certainly evolved and can be considered as a traditional or modern secular journey. Nevertheless, the spiritual experience and search of spiritual fulfilment are still the core phenomenon of pilgrimages (Digance, 2003; 2006). In recent times the lines between pilgrimage and tourism have come so closer that it is difficult to differentiate between the two. Singh (2013) explicitly provides a significant difference between a pilgrimage and touring. Touring is associated with the outer journey in the geographical place, mainly driven by curiosity or pleasure-seeking. On the other hand, pilgrimage is associated with a journey within oneself in an exterior space where the immanent and the transcendent together create a complex phenomenon. Husein (2018, p. 10) argues that "in contemporary literature, religious pilgrimage is treated as a subcategory of modern pilgrimage", which includes a religious journey to a sacred site. The sites can be of various types such as environmental sites including mountains, rivers, caves, groves and even animals. It can also be the religious sites mainly human-made such as churches, temples and shrines or can be a locus associating religious activities, fairs, festivals and religious rituals.

\section{Characteristics of Pilgrimage}

Pilgrimage involves one of the most fundamental characteristics: the movement which can be in different forms. This movement includes travel or journeying and completing the rituals and customs associated with the pilgrimage, and the travel range from long distances routes, for instance, Camino de Santiago in northern Spain, to Mecca which is more compact. Scott (2012), as cited in Singh (2013) also supports the idea; asserts that pilgrimage is associated with travel to the pilgrimage site, which can be a natural sacred site or human-made. Shinde (2007) views that pilgrimage has three key elements and travel or journey in pilgrimage is one of the most important among all societies. Besides journey, pilgrimage is backed up with majorly spiritual motivation, keeping aside the secular life for a while. On reaching upon the sacred site with religious motivation and a spiritual journey undertook, pilgrims, perform certain rituals to "see and be seen" by God (Shinde, 2007, p. 343). Other than these three significant pilgrimage elements, Stoddard (1997) explains that pilgrimage comprises the fourth element"magnitude", which varies according to the interpretation. Shinde (2007) argues that pilgrimage is usually a personal affair; however, it also includes people's mass movement at a time. Likewise, Di Giovine \& Choe, (2019: 362) writes "the nature of visits may also be different from performing in groups to the prescribed religious rites (e.g. hajj to Mecca, Kumbh Mela in Allahabad, pilgrimage to Lourdes) to selfprescribed pilgrims may make the pilgrimage to memorials and other sites of loss, to their imagined homelands and heritage sites, to places and landforms to the individual".

Scriven (2014) highlighted the characteristics of pilgrimage. He described the first feature of pilgrimage being the "movement" of people, including travelling and performing rituals. The second feature of pilgrimage is its spatial nature 
as it includes pilgrim's origin places, the destination sites, the intermediary sites between the origin and destination of pilgrims and routes taken by the pilgrims. The third important feature of pilgrimage is the belief which, according to him, is a crucial part of the journey. Lastly, pilgrimages modify the cultural landscape, thus act as a transforming agent.

\section{Performing Pilgrimage}

Whether it involves a short journey or a long one or it is performed by an individual or in a group, every pilgrimage has religious practices and
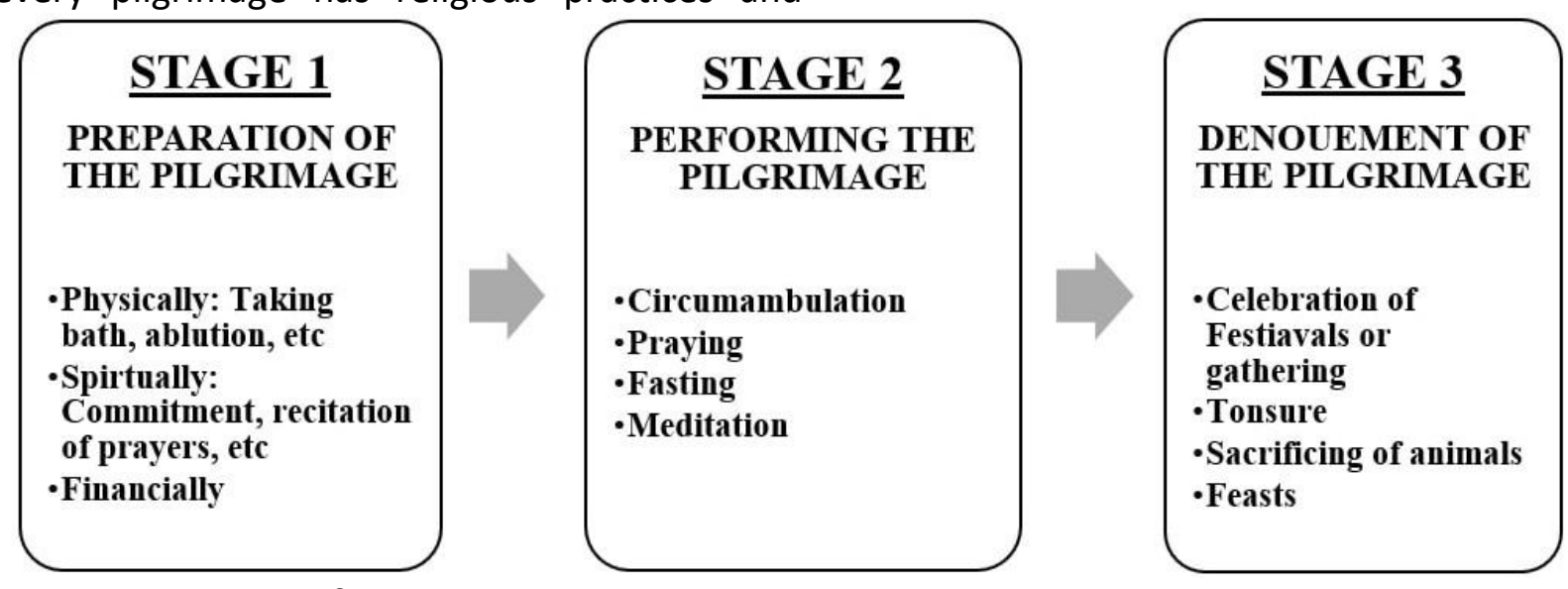

Figure 1: Process of Pilgrimage

Source: Developed by the Authors from Various Published Literature

Singh (2011), in his study, discussed the three stages of pilgrimage in Hindu tradition. The first stage is 'initiation', which includes when an individual decides to take the religious journey and begins the journey. The second stage is 'liminality', which includes the whole sacred journey itself and pilgrimage experiences. The final stage is 're-aggregation' in which the pilgrims return to their home.

More or less, the pilgrimage can be recognised in three stages (Figure 1). In the first stage, the pilgrims prepare themselves physically, spiritually and financially for the sacred journey. The second stage involves encountering the activities in the pilgrimage sites such as circumambulation around the holy structure, praying at the site, fasting and meditating. The last stage involves the climax of the spiritual journey and performing the activities to enclose the pilgrimage and return home. processes involved. Supporting the view, Courtney (2015, p. 173) asserts that "pilgrimages have several common elements, with various authors identifying a process with common stages including the call, the preparation, the performance and the return." Two sets of activities regarding pilgrimage have been addressed by Davidson \& Gitlitz (2002). One involves all the activities and rituals performed in between the pilgrimage journey, and the other includes all the activities performed in the pilgrimage sites.

\section{Classification of Pilgrimage}

Though pilgrims' primary objective to undertake pilgrimage remains the spiritual benefit, several scholars have attempted to classify the pilgrimage based on different criteria. Turner (1973) explains two types of pilgrimage. The first is the obligatory pilgrimage, which involves compulsory visitation accompanied by a set of rules to be followed in the whole pilgrimage. The other is the voluntary pilgrimage which is mainly accompanied by wishes or vows.

Ebadi (2015, p.70-73) has classified the pilgrimage depending on visitors' motivation into two main categories: 'religious' and 'secular' pilgrimage. He defines the religious pilgrimage as the "pilgrimage performed by traditional believers who are -only with holiness and worship in reference to a higher or supernatural deity or being(s)". Whereas the secular pilgrimage is taken by the pilgrims, whose main motive is to visit the sacred place, but there are 
several other motivations accompanied by the journey. Further, he subcategorises the secular pilgrimage in three types based on the motivations, namely, cultural, political and nostalgic (Ebadi, 2015).

People may also come from nearby areas or travel from a very long distance. Therefore, another criterion for classifying the pilgrimages is the catchment areas of the pilgrims. Stoddard (1997) in his study aptly classifies this ordinal scheme of representation of pilgrimages. Based on the percentage of pilgrims who have travelled specified distances, he divides the pilgrimage as regional, national and international. In an explanation, he further states:

if more than 30 per cent of the pilgrims to a particular site are categorised as international, the event they are attending could be considered an "international" pilgrimage; If fewer than 30 per cent of the pilgrims are international, but more than 50 per cent are national, then the occasion might be classified as "national", according to this proposed scheme, all other pilgrimages would be classed as "regional" (Stoddard 1997, p. 51).

\section{Authorisation of Pilgrimage}

Authorisation of pilgrimage is a process by which a pilgrimage site gets the formal recognition either sanctioned by the authorities, holy texts, or oral history. Stoddard (1994) in his study "Major Pilgrimage Places of the World" followed the three approaches to differentiate the importance of pilgrimage place. The first is to rely on religious literature. Secondly, to observe the pilgrims that visit a sacred site and the third is to "accept the judgement of a panel of experts". In their study, Di Giovine and Choe (2019) discussed the pilgrimage's authorisation process briefly. They presented three ways by which the sacred of pilgrimages are authorised: through tradition, through canonical text and institutional norms. The first form of authorisation is by tradition. The society recognises a place to be sacred which does not have to be necessarily officially proclaimed, but rather be a traditional thing that is going on with time from the past. These mostly occur in an indigenous belief system where there are no formal or institutional centres of power; the second form of authorisation comes from narratives mostly by the sacred books. The third form of authorisation provides recognition to the pilgrimage places is a normative authorisation. Political purposes often back up a religious authorisation. However, many pilgrimage sites are resulting from modern tourism's growth and have become secularised in nature.

\section{Pilgrimage in Islam}

\section{Typology}

In most of the major religions, pilgrimage is not included as an obligatory act to perform. While in Islam, religious journeys are well authorised by the sacred text of Muslims, which is the Holy Quran. The Quran says:

And proclaim to mankind the Hajj (pilgrimage). They will come to you on foot and on every lean camel, they will come from every deep and distant (wide) mountain highway (to perform Hajj) (1) (The Quran n.d., 22.27)

There are only two basic Islamic sources: Qur'an and Sunna/Sunnah(/Hadith). The Sunna includes the sayings, actions and approval or disapproval of an action the Prophet Muhammad saw or heard about. The first Hajj was performed in 632 CE under the leadership of the Prophet. He performed his Umrah in 628/629. There is a lot of scriptural notes on the way Hajj has been performed since $632 \mathrm{CE}$. The rites and rituals have been identified since it first began and cemented itself as one of Islam's five pillars. It is performed in the last month of the Islamic calendar, that is, Dhu al-Hijja. It is a yearly Islamic pilgrimage to Mecca (Saudi Arabia) considered to be the holiest city for Muslims. Hajj is a compulsory religious obligation on every rich Muslim, not for the poor ones, which has to be performed at least once in their lifetime, only if he/she is physically and monetarily capable; and, can bolster own family during own absence while on this pilgrimage. The basic Islamic texts 
have approved both Hajj and Umrah. Hajj is compulsory only once in a lifetime, while one can go for Umrah as many times as possible. Some rich people perform Hajj every year or more than once in their life.

The other pilgrimage associated with Islamic tradition is Umrah. Umrah is sometimes considered as the 'lesser pilgrimage'. Pilgrims can go to conduct the rituals at any time of the year. Umrah is not compulsory but is highly recommended. The usual Umrah times are the days before, during and following the Hajj and during the final days of Ramadan (the ninth month of the Islamic calendar). Almuhrzi and Alsawafi (2017, p. 235) in their study with the assistance of hadiths explain the reasons: "Firstly, it was an old hadith or saying of the Prophet Mohammed's that suggests that undertaking Umrah in Ramadan ("Umrah in Ramadan equals a Hajj with me") (Saabiq, 2004) brings good fortune and reward; and secondly Muslims believe that Ramadan was the first time Mohammed received verses of the Quran, marking it as an auspicious occasion."

Hajj and Umrah are not the exclusive religious journey that the Muslims take. As per Islamic customs, Muslims are urged to travel, not exclusively to hold up under observer to God's significance, yet in addition to pick up information, find out about different societies, and meet devout shrewd men. In his study, Bhardwaj (1998) provides the classification of Islamic pilgrimage and divides it into two broad categories; the first is an obligatory pilgrimage, and the other is a voluntary pilgrimage (Figure 2). As it has been already mentioned that Hajj is an obligatory pilgrimage, the second category of pilgrimage includes ziyarat or ziyarah. Meri (2015, p. 508) also mentions ziyarah as another form of pilgrimage known in the Islamic world. He defines it as "the act of pilgrimage and pious visitation to any holy place to Islam. The Islamic context refers to non-canonical pilgrimage, that pilgrimage other than the Hajj and Umrah to Mecca."

Ebadi $(2015$, p. 66) provides a clear description of the two types of pilgrimage in Islam. He states "the Hajj (pilgrimage to Mecca) which is considered as the official or normative form of pilgrimage in Islam. Ziyārat has been considered the 'popular' (that is, völkisch) form of pilgrimage, full of local cultural aspects and practised in different forms among people from different cultures. In other words, ziyarat, with its unwritten rules manifests the variegated culture of Islam in various regions." All around the Muslim world including North Africa, Middle East, Central Asia, to the south and south-east Asia, pilgrimages to the Muslim shrines hold immense importance in people's social life's (Rowley, 1989). Shrines, mosques, tombs dedicated to prophets, imams, saints, Sufi saints, and other holy people including both men women, are the sites of pilgrimages or ziyarat for Muslims (Ebadi, 2015; Rowley, 1989).

\section{Popular Pilgrimage in Islam: Ziyarat}

Ziyarah or Ziyarat, means visitation in Arabic, is a form of pilgrimage to venerated sites associated with Prophet Muhammad and his descendants and venerated figures and associated holy objects in Islam. After the Hajj, visiting the Al-Masjid an-Nabawi (the prophet's mosque) is an example of Ziyarat. Despite being an optional visit, it is a common act. Likewise, visiting Jerusalem's Al Aqsa Mosque, considered the third holiest city after Mecca and Medina, is a prime Ziyarat destination.

While the above-mentioned holy sites of Islam are of pan Islamic importance, there is a coexistence of numerous pilgrimage sites of regional importance. Many places exist in the Muslim World, each serving distinct purposes and needs having diverse and sectarian views. The religious circulation is seen in mosques, Zawiya or Khanqah (Sufi lodges), Dargah/Mazar, Jamaat-khanaah (Ismaili houses of the congregation), Twelver Shiites Husayniyahs and Imambaras (Ebadi, 2016). People visit these places for a variety of reasons (Figure 2), such as participating in the saint's death anniversary, commemorating a special day of martyrdom, celebrating prophet's birthday, religious occasion related to venerated persons, seeking blessings of the saint known as baraka, the fulfilment of vows, looking for the cure of 
ailments and even psychosomatic diseases (Bhardwaj, 1998).

\section{Veneration of Saints}

Muslims make pilgrimages to the saintly figures that had significant political, religious, and military contributions such as Sufis, the scholar's theologians, and rulers (Mulder, 2014). After a saint gets designation, Muslims make pilgrimages or ziyara to their shrine in order to obtain baraka (blessings) through prayer and supplication. Goldziher (1971) in his seminal work "The Veneration of Saints in Islam" has mentioned how the idea of saint veneration exists within Islam, or what is the reason of the existence of saint veneration and how it has evolved in Islam. He claims two reasons for its presence; the first is the need to replace preIslamic God's and second, an attempt on the part of early followers to emphasise the miraculous gifts of Prophet Muhammad.

Elaskary and Yun (2017), with the assistance of hadiths, assert that Prophet Muhammad prohibited visiting the graves at the initial stage of Islamic mission. Later he removed this restriction, and himself started visiting the graves of his companions who died in the war and prayed for them. However, this act did not approve of performing certain acts which were not related to Islamic tenets. Such as, sacrificing animals on behalf of the dead and praying to them for their assistance in the graveyards. There has been distinction done by the Islamic scholars regarding ziyara of which are lawful and acceptable and what is innovative and heathenish. What is acceptable in ziyara is, if someone passes by a grave or a shrine, he can pray for the dead person and recite Quranic verses. What is not acceptable and regarded as innovative ziyara is travelling especially to the shrines and staying there and worshipping the awliya (saints). It is not acceptable in Islam to intercede between God and the person, including Prophet Muhammad as well. The objective of doing so is not to imitate other traditions such as tribal or folk traditions and maintain the religion's basic tenets.

Ferg (2008) has also discussed the growth of the ideas of saint veneration. He asserts that
Prophet Muhammad in his life denied the ability to perform miracles or predict future events. Despite that, his followers and biographers started adding the miraculous notion to his profile. Afterwards, the ruler obtained the relics and used as a source of blessings and legitimacy of their ruling. In fact, after their passing away, they used to get buried with the relics. Side by side, growth was also seen in the veneration of saints, and other holy person and the majority of Muslims did not care much about the justification of this practice. The prophet's family, including his daughter, cousin, and the prophet's companions in Medina, saints, and local rulers, were venerated. The pilgrims visited their graves to pay respect and seek blessings which are known as baraka in Arabic. An Islamic mystical movement known to be Sufism added the development of saint veneration in the 8th Century as it emerged (Ferg, 2008). Sufis were dedicated Muslims who did not attach themselves with worldly affairs and refused to follow Umayyad caliphates' unrighteous actions, second of four major Islamic state rulings between 661-750 CE (Encyclopaedia Britannica, n.d.). Thus, they engaged themselves to their own sacred beliefs in order to follow the prophet properly. The famous and well-known Sufis came to be venerated as their category.

Mulder (2014) in studying the shrines of Central Islamic lands have discussed the reasons of current practices of ziyara to be the result of three leading causes: the continuation and elaboration of pre-Islamic devotional practices from the biblical prophets and holy figures of the Jewish and Christian traditions; reverence for the prophet's family- a sentiment shared by all Muslim communities, though particularly pronounced within Shi'ism; and lastly veneration of learned rulers, preachers, scholars and Sufis, a phenomenon that became widespread in the twelfth and thirteenth century. He further explained that although the cultures of saint veneration or visitation to the graves flourished after the martyrdom of Shias' holy figures, the graves were also visited by Sunnis. However, the sources also prove that the reverence of tombs was present from the beginning in the Islamic 
community and was to be seen in the prophet's

family's burial places.

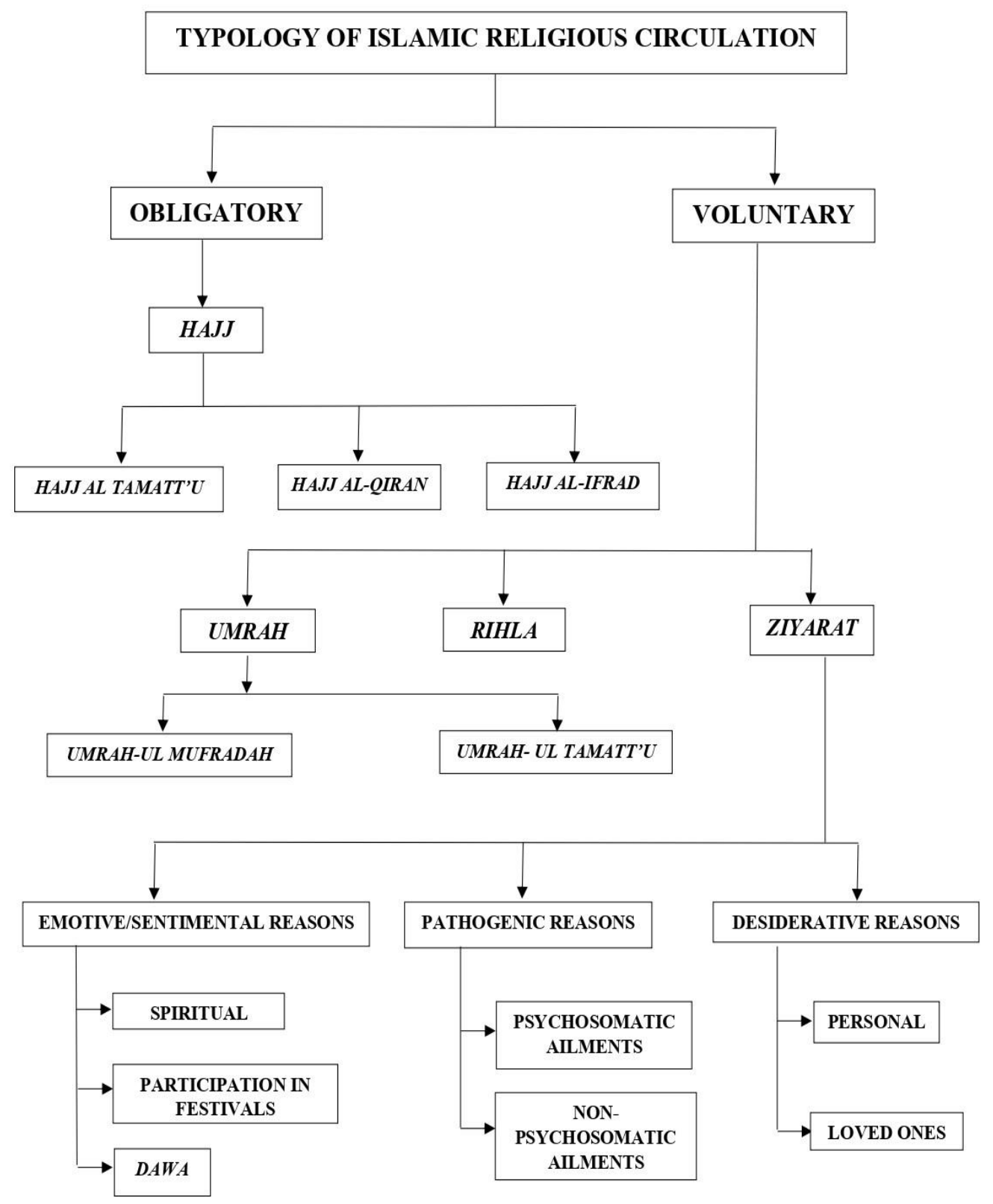

Figure 2: Typology of Pilgrimage in Islam

Source: Adapted from Bhardwaj, 1998

\section{Veneration of Relics}

The Islamic holy relics are visible and tangible objects known in Arabic to be the prophet's relics (asar nabawiyya) (Komaki, 2013). The Islamic rulers have revered these relics. For instance, Abbasid Caliphs used to wear the cloak of Prophet Muhammad on various occasions. These relics are known by different names in South Asia such as tabarrkat, asar-e Mubarak and asar e-sharif. The terms share a common root having the word " $b-r-k$ " which has the meaning in Arabic as baraka (Komaki, 2013).
Ferg (2008, p. 8) explains "baraka can be translated blessed virtue and spiritual potency to power and even luck, and baraka is an innate force. . . Which prophet's and saints possessed as did objects and places with which they came in contact." Meri (2002, p. 17) describes baraka as "spiritual, perceptual, and emotive, rather than conceptual. More precisely, baraka is the emanation and perpetuity of holiness in the person of a saint, which manifests itself in objects, or persons with whom he has come into contact posthumously or during his life." God 
endows saints with baraka, who transmits it on to the faithful. The saint's baraka sought by pilgrims and supplicants be transmitted in several ways. First, and most common, it can be transmitted by direct contact- either through physical and contact with the saint or through contact with the saint's tomb and shrine and second, one may obtain a saint's baraka by possessing relics or objects, such as clothing, associated with the saint. The third one may receive baraka by coming upon a saint in a dream (Ferg 2008).

Komaki (2013) also mentioned the presence of holy relics belonging to Prophet Muhammad such as hair or beard, footprint, sandals, cloak or staff present and kept safely in the Muslim shrines and other institutions which are venerated heartedly and visited as pilgrimage sites. For instance, the shrine of Hazrat Nizamuddin Auliya in New Delhi (India) reportedly has several hairs of beard belonging to Prophet Muhammad, a small leather part of the book written by Hazrat Ali, a small brick covered in the blood of Hazrat Hussain, its colour changes from brown to red every year on his death anniversary and footprint of the prophet. These relics are venerated in the shrine and are opened for the public once in a year on the occasions of prophet's birth anniversary. Komaki (2013) also brought two strongpoints in his study, firstly, in many cases, the saints in saint cults have markedly local quality, but the holy relics are held to be relics of the program and his family or descendants. They can be considered to possess a mere universal quality that evokes a temporal and spatial centrality. Thus, the local shrines gain significance by displaying the holy relics of global importance. Secondly, pop charms and amulets having imprints of holy relics at low prices in the local shrines regenerate and shape the faith continually. It reinvents and transforms with time venerated in sacred places but also on personal spaces.

\section{Reasons for Performing Ziyarat}

There are several reasons for which Muslim undertake the Ziyarah. The Muslims venerate the entombed figures to seek blessings and grant wishes as they are believed to be a mediator to
God, and thus requests can be answered quickly. Ebadi (2016), while studying the shrines of Turco-Iranian regions mentions that most of the shrine visitation is done to seek the saint's blessings because of the belief that these saints have baraka. Thus, people ask for spiritual guidance or request assistance for various daily life problems, such as personal health. Ortis (2017) while studying the three famous shrines in South Asia namely Ghāzī Miyāñ (India), Lāl Shahbāz Qalandar and Bodlo Bahār (Pakistan) explains that although it is said that the saints belonging to these shrines grant all the wishes and vows, but people mainly visit these shrines for spiritual assistance, and for acquiring peace. They also pray for the best in the other world or hereafter. In her study, Asher (2009) mentions that different reasons for people's visitation in the shrine named Nagore shrine (Tamil Nadu). She claims that Muslims and Hindus and Christian visit the shrine for seeking cures of ailment, taking blessings for having a baby and also for a safe journey as the saint is known for its capability of saving ships.

The ziyarat is not only done for personal reasons. Papas (2013) asserts that in the Muslim world and particularly in Xinjiang (China) people do ziyarat on various occasions and different times of the year. For instance, religious festivals like al-mawlid (the birthday celebration of Prophet Muhammad or a Sufi saint) and Qurban (when animal sacrifice is made as a rite performed during the great festival (al-Eid al-Kabir), at specific religious periods in the year like Ramadan, Muharram, and Shab-e-Barat, people also visit in the starting of a season mostly during spring and on specific days mainly on the days after the Friday prayer and preaching at the mosque.

People not only visit individually to the shrines; the visitation is also done in a group at a time. For instance, in the Nizamuddin dargah, the religious gathering takes place on one of the important occasions, the prophet birth anniversary, where the relics are displayed once in a year. People gather to attain the baraka emitted by the relics. The power of relics is so strong that they transform the shrine to a spot 
where the believers can get together with prophets and his family (Komaki, 2013).

Beattie (1983) addressed the reason for visitation in Iran and Afghanistan's shrines and concluded that one reason for people's visitation to the shrines is worldly affairs where sickness and physical handicap are the most common concerns of visitations. Where there are some particular shrines associated with ailing the diseases, he also mentions another dimension in which people visits the shrine because of political circumstances as they reside there and protest against the government. Boissevain (2016) also mentions the visitation of people in numerous urban and rural shrines known as zawiyas that attract pilgrims every week and on certain occasions such as the birth anniversary of holy men and seldomly women. These celebrations are locally known as Moussem in the Maghreb.

Thus, it can be said that the nature of visits differs mostly. The religious visits are done individually as well as in group on various occasions such as birth anniversaries of saints or prophet's birthday. The reason for visitation is different and varies from individual to individual and from shrine to shrine.

\section{Contradictory views on Ziyarat}

Even though all Muslims pursue a similar holy book (Quran) and the saying of the Prophet Muhammad (PBUH), the degree of customs, religiosity, and elucidation is not the same from nation to nation and clearly from individual to individual. Numerous elucidations of Islam (now and then conflicting) exist together, next to each other, with the supporters of every contending that they have appropriate knowledge of the religion. As jurisprudence (figh) and jurisprudential laws change from country to country, we see a great deal of diversity in religious understanding among Muslims all around the world having their unique religious codes. Islam involves numerous sects based on the school of thoughts. However, the two main and the earliest division within Islam to exist is Sunni and Shi'as. The division between these two sects occurred shortly after the death of Prophet Muhammad. Prophet Muhammad did not select a successor before his death. Thus, the argument of holding the ruling position and further increasing political tensions led to the division of Islam (Doud, 2016). In her study, Mulder (2014) mentions that the views vary regarding shrine visitation among different Muslim sects. She asserts that the notion of ziyara has existed in both Shia's and Sunni's religious aspects. She further states "while Sunni and Shia shrine visitations are often discussed as two separate and non-overlapping phenomena in which Sunnism objected the practice while Shi'ism embraced it." In the case of Sunni's, the legality of the practice has been questioned and has been a topic of debate, however for Shia's because of their devotion towards the prophet's family the practice of ziyara have a vital role. Shias never attempted the tradition of questioning the legality or interrogating the practice of shrine visitation; however, in Sunni legal circles; the topic has been debatable.

Ferg (2008) points out that Hajj is incumbent upon all Muslims to take once in their lifetime. However, being an expensive affair, mostly to the lower-income groups, it is mandatory for rich Muslims only, as mentioned before. Visitation to the shrines and tombs of saint's or their pilgrimage is common and mostly among Shia's. While for Sunni Muslims, the shrines and tombs' visitation is not regarded as a substitute to Hajj. She further points out the rituals associated with Hajj and ziyara are somewhat similar for instance, both involve a journey, circumambulation, a debate has been developed in the practice of ziyarat and being it as a subsidiary Hajj.

Wahhabism is an Islamic religious movement found by the legal scholar Muhammad Ibn Abd al Wahhab in the lands of contemporary Saudi Arabia. It is regarded as an ultra-conservative and orthodox interpretation of Islam that seeks to revive Islam's original teachings based on two primary sources of knowledge: Quran and hadiths (Roof \& Juergensmeyer, 2012). Ibn Taymiyyah, one of the theologians supporting this school of thought asserted that pilgrimage to the shrines of saints, asking for their blessings is regarded as shirk (polytheism) as well as one 
of the severe sins in Islam. Wahhabis, the largest group of Muslims among the other schools of jurisprudence, view ziyara as an innovation or Bida in Islam and regretted saints' veneration (Woodward et al., 2013).

Elaskary and Yun (2017) mention that mostly the uneducated and poor visits the shrines when they suffer from hardship or in the times of calamity and ask for assistance and help on behalf of them to God. They explored the differences of views among Muslim sects regarding the shrines of saints. Firstly, they assert that the shrine construction, visitation, and status of saints differ mainly from country to country because of economic, educational, ethnic, and political conditions. It is the cultural factors that lead to the view of Saint visitation. Thus, most of the shrines are present in the Shia dominated and South Asian countries and absent in the Gulf countries which follow the traditional Sunni Islamic views. While the Sunni Muslims believe in the special status of awliyā, they refuse the right given to them to fulfil any wishes on behalf of God. In comparison, the Shias and Ahmadiyya ask assistance from saints and pray for help.

Ebadi (2016) studied the shrine pilgrimage in the Turco-Iranian region and provided insight into the views of ziyarat among Sunni and Shia's. As in Sunnis' case such as Wahhabis, he assists, as Wahhabis prohibit the worship of saints and going to the pilgrimage they regard it to be unIslamic, as they view that prophet himself prohibited such events to his grave also. Thus, no shrine was built upon the graves of the first three Caliphas in Islam. However, for the Shias, the first imam, Ali ibn Talib, the fourth caliphate according to Sunni Muslims, a golden shrine has been erected along with Hussain's shrine, the son of Ali, which is revered as the holiest shrines among Shia Muslims of Iraq. Rahmatullah (2014) views are quite contradictory on shrine visitation. He claims that going to the Mazars is more common among Sunni Muslims, but Shia also visits the Mazars; however, the practice is more common among Sunnis. Shias also visit the Mazar if they get to know a place where wishes get fulfilled successfully. Describing the view of a prominent Shia Muslim named Mr Alam Hussain who belongs from Banaras, he says Shia only visits the first twelve imams' mausoleum. They do not regard the visitation of Mazar as a duty.

\section{Future Research}

Given the diverse nature of Islamic pilgrimage, it provides a vast canvas on future geographical research. The Islamic pilgrimage needs more attention by geographers and demands a theoretical base by qualitative investigations, especially regarding the popular pilgrimage in Islam, that is, ziyarat. This pilgrimage does not have authorisation by the Quran and hadith, which are the source of guidance and religious law by Muslims globally. Therefore, being a cultural phenomenon, the narratives of the pilgrims to the Muslim shrines could contribute to understanding the making of the sacred space. Furthermore, some holy sites bring pilgrims all across the world. A little quantitative data is reported, which creates a significant gap and creates difficulty for spatial and temporal analysis of pilgrimage sites.

With the growth of religious movements such as Wahhabism whose primary objective is to restore Islam's original teachings, there has been a transformation in shrine visitations' practices. A longitudinal study to see the growth or decline of these Islamic shrines can contribute to understanding these popular pilgrimages. Another crucial geographical inquiry could be from a feminist perspective. The Muslim shrines create a gender-space with considerable involvement of female pilgrims.

Mecca acts as a central axis that brings millions of Muslims to perform Hajj and Umrah and dissipates all the differences that divide Muslims on their own about sect, language, caste, and race. An investigation on the impact of these obligatory pilgrimages on the voluntary pilgrimages could be considered.

\section{Conclusion}

This study has sought to demonstrate an overview of pilgrimage by describing its changing meaning, common elements, processes involved, classification, and authorisation. The study identifies the rich and complex forms of 
pilgrimage in Islam. Usually, the Islamic pilgrimage is recognised by the obligatory pilgrimage, that is, Hajj. Indeed, Hajj and Umrah recognise the sacred texts. However, ziyarat is such a common form of the pilgrimage that cannot be overlooked. The Muslims share Islam's core beliefs; however, there are diverse cultural practices that do not go with the Islamic beliefs' tenets. Future research should be conducted on the themes identified to bring more conceptual clarity of these religious journeys in the Islamic world.

\section{References}

Almuhrzi, H. M., \& Alsawafi, A. M. (2017). Muslim perspectives on spiritual and religious travel beyond Hajj: Toward understanding motivations for Umrah travel in Oman. Tourism Management Perspectives, 24, 235-242. https://doi.org/10.1016/j.tmp.2017.07.016

Asher, C. B. (2009). The Sufi Shrines of Shahul Hamid in India and Southeast Asia. Artibus Asiae, 69(2), 247-258.

https://www.jstor.org/stable/20801622

Barber, R. (1991). Pilgrimages. Boydell \& Brewer Ltd.

Beattie, H. (1983). Tombs and footprints: Islamic shrines and pilgrimages in modern Iran and Afghanistan. MPhil thesis. SOAS University of London.

Berriane, J. (2015). Pilgrimage, spiritual tourism and the shaping of transnational 'Imagined Communities': the case of the Tidjani Ziyara to Fez. The international journal of religious tourism and pilgrimage, 3(2), 1-10. https://doi.org/10.21427/D7GX30

Bhardwaj, S. M. (1983). Hindu places of pilgrimage in India: A study in cultural geography. University of California Press, Ltd.

Bhardwaj, S. M. (1998). Non-hajj pilgrimage in Islam: A neglected dimension of religious circulation. Journal of Cultural Geography, 17(2), 69-87.

https://doi.org/10.1080/08873639809478321

Boissevain, K. (2016). Studying religious mobility: pilgrimage, shrine visits and religious tourism from the Maghreb to the Middle East.
In D. Albera. J. Eade (Eds.), New pathways in pilgrimage studies (pp. 101-117). Routledge. Collins-Kreiner, N. (2010). The geography of pilgrimage and tourism: Transformations and implications for applied geography. Applied geography, 30(1), 153-164. https://doi.org/10.1016/j.apgeog.2009.02.001

Courtney, M. (2015). A review of the literature exploring the occupation of contemporary pilgrimage. Journal of Occupational Science, 22(2), 170-182.

https://doi.org/10.1080/14427591.2013.76481 6

Dauda Goni, M., Hasan, H., Naing, N. N., WanArfah, N., Zeiny Deris, Z., Nor Arifin, W., \& Abubakar Baaba, A. (2019). Assessment of knowledge, attitude and practice towards prevention of respiratory tract infections among Hajj and Umrah pilgrims from Malaysia in 2018. International journal of environmental research and public health, 16(22), 4569. https://doi.org/10.3390/ijerph16224569

Davidson, L. K. \& Gitlitz, D. M. (2002). Pilgrimage: From the Ganges to Graceland: an encyclopedia. Abc-clio.

Desai, M. (2003). Mosques, temples, and orientalists: Hegemonic imaginations in Banaras. Traditional Dwellings and Settlements Review, 23-37.

https://www.jstor.org/stable/41758028

Di Giovine, M. A. (2019). Geographies of religion and spirituality: Pilgrimage beyond the 'officially'sacred. Tourism Geographies, 21(3), 361-383.

https://doi.org/10.1080/14616688.2019.16250 72

Digance, J. (2003). Pilgrimage at contested sites. Annals of tourism research, 30(1), 143-159. https://doi.org/10.1016/S0160-7383(02)000282

Digance, J. (2006). Religious and secular pilgrimage: Journeys redolent with meaning. In Tourism, religion and spiritual journeys (pp. 5264). Routledge.

Doud, B. T. (2016). The Sunni Shia Split: Perplexing and deadly international 
intercultural conflict. Global Security Studies, $7(2)$.

http://www.globalsecuritystudies.com/Doud\%2 OSunni\%20Shia.pdf

Ebadi, M. (2015). Forms of pilgrimage at the shrine of Khāled Nabi, Northeastern Iran. International Journal of Religious Tourism and Pilgrimage., 3(1), 66-78.

https://doi.org/10.21427/D72M7P

Ebadi, M. (2016). Shrine pilgrimage (Ziyārat) in Turco-Iranian cultural regions, International Journal of Religious Tourism and Pilgrimage, 4(1), 70-77. https://doi.org/10.21427/D74M8P

Elaskary, M., \& Yun, E. K. (2017). Death, resurrection, and shrine visitations: An Islamic perspective. Religions, 8(3), 2-11.

https://doi.org/10.3390/rel8030034

Encyclopedia Britannica. (n.d.). Umayyad dynasty.https://www.britannica.com/topic/Um ayyad-dynasty-Islamic-history

Ferg, E. (2008). Islamic saint veneration: Iran. University of Denver.

Goldziher, I. (1971). Muslim studies, Translated by CR Barber and SM Stern. Gerge Allen \& Unwin Ltd.

Husein, U. M. (2018). A phenomenological study of Arbaeen foot pilgrimage in Iraq. Tourism Management Perspectives, 26, 9-19. https://doi.org/10.1016/j.tmp.2017.11.015 Jackowski, A. (1987). Geography of pilgrimage in Poland. In Trends in the Geography of Pilgrimages. Homage to David E. Sopher. The National Geographic Journal of India, 33(4), 422-429.

Kessler, K. (2015). Conceptualizing Mosque tourism: A central feature of Islamic and Religious Tourism. The international journal of religious tourism and pilgrimage, 3(2), 11-32. https://doi.org/10.21427/D7RB0G

Kinell, N. (2017). Christianity in Banaras: A mapping of Christian congregations and case study on two Catholic churches (Dissertation). 44.

http://urn.kb.se/resolve?urn=urn:nbn:se:kau:di va-47826
Komaki, S. (2013). The cult of Islamic holy relics as a contact zone: A case study of a Muslim Shrine in North India. Studies of regional policy, 15(3), 27-39.

https://tcue.repo.nii.ac.jp/?action=pages_view_ main\&active_action=repository_view_main_ite m_detail\&item_id=91\&item_no $=1 \&$ page_id $=13$ \&block_id=21

Meri, J. W. (2002). The cult of saints among Muslims and Jews in medieval Syria. OUP Oxford.

Meri, Y. (2015). The cult of saints and Pilgrimage. In A. J. Silverstein, \& G. G. Stroums (Eds.), The Oxford Handbook of the Abrahamic Religions (pp. 499-517).

0.1093/oxfordhb/9780199697762.013.19

Morinis, A. (1992). Sacred journeys: The anthropology of pilgrimage. In Contributions to the Study of Anthropology (Vols. NS15-2, pp. 128). Greenwood Publishing Group.

Moufahim, M., \& Lichrou, M. (2019). Pilgrimage, consumption and rituals: Spiritual authenticity in a Shia Muslim pilgrimage. Tourism Management, 70, 322-332. https://doi.org/10.1016/j.tourman.2018.08.023

Mulder, S. (2014). Shrines in the Central Islamic Lands. In The Cambridge History of World Religious Architecture (p. 48). Cambridge University Press.

Nolan, M. L. (1987). Christian pilgrimage shrines in western Europe and India: A preliminary comparison. National Geographical Journal of India, 33(4), 370-378.

Ortis, D. (2017). From potent dead to potent places? Reflections on Muslim saint shrines in South Asia. The Asia Pacific Journal of Anthropology, 18(5), 483-498. https://doi.org/10.1080/14442213.2017.13738 45

Papas, A. (2013). Pilgrimages to Muslim shrines in western China. Living shrines of Uyghur China: Photographs by Lisa Ross. Monacelli Press.

Park, C. (2004). Religion and geography. In J. Hinnells (Ed.), Routledge Companion to the Study of Religion (pp. 414-445). Routledge. 
Puspitasari, P., Djunaedi, S. A., \& Putra, H. S. (2012). Ritual and space structure: Pilgrimage and space use in historical urban kampung context of Luar Batang (Jakarta, Indonesia. Procedia-Social and Behavioral Sciences, 36, 350-360.

https://doi.org/10.1016/j.sbspro.2012.03.039

Rahmatullah (2014). Muslim shrines and MultiReligious visitations as a symbol of peaceful coexistence: A study of three prominent Sufi shrines, Islam and Muslim Societies. A Social Science Journal, 7(2), 51-61.

https://www.muslimsocieties.org/Vol7_2/Musli m_Shrines_and_Multi_Religious_Visitations.pdf

Rinschede, G. (1986). The pilgrimage town of Lourdes. Journal of Cultural Geography, 7(1), 21-34.

https://doi.org/10.1080/08873638609478518

Roof, W. C., \& Juergensmeyer, M. (2012). Encyclopedia of global religion. Sage Publications.

Rowley, G. (1989). The centrality of Islam: Space, form and process. GeoJournal, 18(4), 351-359. https://doi.org/10.1007/BF00772689

Saabiq, S. (2004). Jurisprudence of Sunnah. International Company for Printing.

Scott, J. S. (2012). Representing Sacred Space: Pilgrimage and Literature. In T. Coomans, $\mathrm{H}$. De Dijn, J. De Maeyer, R. Heynickx, B. Verschaffel (Eds.), Loci Sacri: Understanding Sacred Places (pp. 138-167).

https://www.jstor.org/stable/j.ctt9qdxq6

Scriven, R. (2014). Geographies of pilgrimage: Meaningful movements and embodied mobilities. Geography Compass, 8(4), 249-261. https://doi.org/10.1111/gec3.12124

Shair, I., \& Karan, P.P. (1979). Geography of the Islamic pilgrimage. GeoJournal, 3(6), 599-608. https://doi.org/10.1007/BF00186060

Shinde, K. (2007). Pilgrimage and the environment: challenges in a pilgrimage centre. Current Issues in Tourism, 10(4), 343-365.

https://doi.org/10.2167/cit259.0

Singh, R. P.B. (2011). Holy places and pilgrimages in India: Emerging trends \& bibliography. In R. P. Singh (Ed.), Holy places and pilgrimages: Essays on India (pp. 7-56). Shubhi Publications.

Singh, R. P.B. (2013). Hindu tradition of pilgrimage: Sacred space \& system. Dev Publishers \& Distributors.

Snyder, M. (2010). Where Delhi is still quite far: Hazrat Nizamuddin Auliya and the making of Nizamuddin Basti. Columbia Undergraduate Journal of South Asian Studies, 1-29.

http://www.kanzuliman.org/wpcontent/uploads/2020/02/cut-.pdf

Sopher, D. E. (1968). Pilgrim circulation in Gujarat. Geographical Review, 58(3), 392-425. https://www.jstor.org/stable/212564

Stoddard, R. (1994). Major Pilgrimage Places of the World. Geography Faculty Publications, 3, 17-36.

Stoddard, R. (1997). Defining and classifying pilgrimages. In R. H. Stoddard, \& A. Morinis (Eds.), Sacred Places, Sacred Spaces: The Geography of Pilgrimages (Vol. 34, pp. 41-60). Department of Geography and Anthropology, Louisiana State University.

Sykes, J. B. (1982). The concise Oxford dictionary of current English. Based on the Oxford English dictionary and its supplements. Oxford University Press.

The Quran (n.d.). Talal Itani- English Translation of The Quran.

https://m.clearquran.com/downloads/quranenglish-translation-clearquran-edition-allah.pdf

Turner, V. (1973). The center out there:

Pilgrim's goal. History of Religions, 12(3), 191-

230. https://doi.org/10.1086/462677

Woodward, M., Umar, M., Rohmaniyah, I., \& Yahya, M. (2013). Salafi violence and Sufi tolerance? Rethinking conventional wisdom. Perspectives on Terrorism, 7(6), 58-78. http://www.jstor.org/stable/26297065

\section{Conflict of Interest Statement}

Ravi S. Singh declares that he has no 'conflict of interest'. Sarah Ahmad is a recipient of the Junior Research Fellowship of the University Grants Commission (UGC), New Delhi, India. 


\section{Acknowledgements}

The authors would like to put their indebtedness on record to Professor Ashfaq Ahmad Nadwi, an Islamic scholar of repute, Department of Arabic, Banaras Hindu University, Varanasi, India for kindly going through the manuscript and suggesting necessary modifications which have brought qualitative improvement in the article.

\section{Author Contribution Statement}

Ravi S. Singh: Conceptualisation; visualisation; methodology; reviewing and editing; supervision.

Sarah Ahmad: Data curation; writing- original draft preparation and revision. 